ACTA MYCOLOGICA

Vol. 42 (1): 125-128

2007
Dedicated to Professor Alina Skirgietto

on the occasion of her ninety-fifth birthday

\title{
Oyster mycelium on the liquid medium
}

\author{
MARIAN GAPIŃSKI ${ }^{1}$, WANDA WOŹNIAK ${ }^{2}$, MIROSŁAWA ZIOMBRA ${ }^{1}$ \\ and JOANNA MURAWSKA \\ ${ }^{1}$ Department of Vegetable Crops, August Cieszkowski Agricultural University of Poznań \\ Dąbrowskiego 159, PL-60-594 Poznań \\ ${ }^{2}$ Instytute of Plant Origin Food Technology, Wojska Polskiego 31, PL-60-624 Poznań
}

Gapiński M., Woźniak W., Zi ombra M., Murawska J.: Oyster mycelium on the liquid medium. Acta Mycol. 42 (1):125-128, 2007.

The research presents the results of oyster mycelium growth on the liquid medium. The mycelim growth: Pleurotus citrinopileatus Singer, P. djamor (Rumph.: Fr.) Boedjin, P. erynii (DC.) Gillet and P. precoce (Fr). Quél. was tested. The quality and quantity of mycelium was assumed.

Key words: mycelium, liquid cultures, Pleurotus species, edible mushroom

\section{INTRODUCTION}

The interest in oyster production is growing because of the increasing demand on the domestic market and the export possibility of the fresh mushroom. The continuous growth of oyster production requires the big quantity of fresh mycelium, which is the raw material for trade production. It makes big problems to keep the big quantity of fresh multiplication material at the high biological activity level. Storing the trade oyster mycelium even under the optimal condition makes the crop ability worse. Shorter or longer storage of mycelium is not desirable, because of the fall tendency of the crop.

To receive the big quantity of trade mycelium the big quantity of homogeneous parental mycelium is required. Its multiplication in the liquid cultures instead of the steady cultures can be very important for the productions development.

The aim of the conducted tests was to check the usefulness of the two mediums on the growth of 4-oyster species. 


\section{MATERIAL AND METHODS}

The laboratory tests were conducted in the thermostat under the controlled temperature in the Biological Lab of Vegetable Department A. Cieszkowski in Poznań.

The base material for multiplication of oyster mycelium in the liquid cultures was oyster mycelium on the agar medium from the Vegetable Department varieties bank. The mycelium growth on the two mediums: the Hansen und potato medium of the following species Pleurotus citrinopileatus, $P$. djamor, $P$. erynii and $P$. precoce was compared.

The Hansen medium was prepared by dissolving $0,3 \mathrm{~g} \mathrm{KH}_{2} \mathrm{SO}_{4}, 0,2 \mathrm{~g} \mathrm{MgSO}_{4}$ $5 \mathrm{~g}$ glucose in the distilled water as well as $1 \mathrm{~g}$ peptone which was first dissolved in $100 \mathrm{~cm}^{3}$ warmed water, and than added do the remaining components of medium. The dissolved and mixed components were filled with water to the volume of $1 \mathrm{dm}^{3}$.

Potato medium was prepared with $200 \mathrm{~g}$ potatoes, pilled and cut into small pieces. These potatoes were cooked in $1 \mathrm{dm}^{3}$-distilled water. After cooking the water was strained and $1 \mathrm{~g}$ of glucose were added and the vaporized water was refilled.

The prepared medium was filled into the $250 \mathrm{~cm}^{3}$ bulb. Each of them contained $150 \mathrm{~cm}^{3}$ of medium. Next the bulbs were closed with the lignin cork an additionally secured with aluminum foil. The mediums were sterilized in the autoclave in the temperature of $121^{\circ} \mathrm{C}$ under the pressure of $0,1 \mathrm{Mpa}$ for 20 minutes.

Next day after preparing the medium, inoculation was done. The mycelium used for the inoculation was taken from the surface of the agar medium, the piece $3 \times 4$ $\mathrm{mm}$ was inoculated onto the liquid medium on the table with laminar air circulation. Incubation was done in the thermostat, in $24^{\circ} \mathrm{C}$ and $90 \%$ air humidity.

All presented results were received form the $150 \mathrm{~cm}^{3}$ medium and were conducted twice in 6 repetitions.

\section{RESULTS}

The mycelium multiplied on the liquid medium in the stationary conditions in the incubator in $24^{\circ} \mathrm{C}$ was growing generally on the surface in the form of firm thallus. Depending on the oyster genus the color of superficial mycelium thallus was between white to light gray-pink with numerous loose hyphae inside the medium.

The results have shown the significant differences in the fresh mass of oyster mycelium depending on the medium and genus. The biggest fresh mass was received on the Hansen medium (7,29 g) irrespective of the oyster genus and essentially lower mass was received on the potato medium $(2,16 \mathrm{~g})$. In all tested oyster genus (Fig. 1) the received mycelium essentially varied depending on the medium. The exception was Pleurotus djamor where the differences in the fresh mycelium were inessential depending on the medium. Essential differences in the mycelium size depending on the medium showed Pleurotus precoce, $P$. citrinopileatus and the biggest showed P. erynii. The fresh mycelium mass $P$. erynii was almost 3 times higher on the Hansen medium comparing to the mycelium mass on the potatoes medium. 


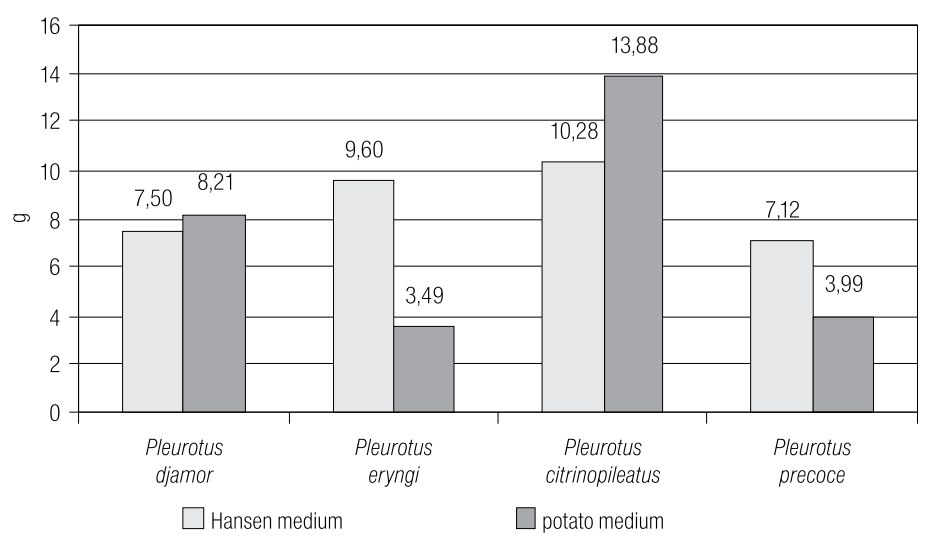

LSD $_{\mathrm{P}=0.95}$ for medium 0.68; LSD $_{\mathrm{P}=0.95}$ for species 0.41 ; $\mathrm{LSD}_{\mathrm{P}=0.95}$ for medium and species 0.96

Fig. 1. Fresh mycelium mass in the liquid stationary cultures depending on the medium and oyster genus.

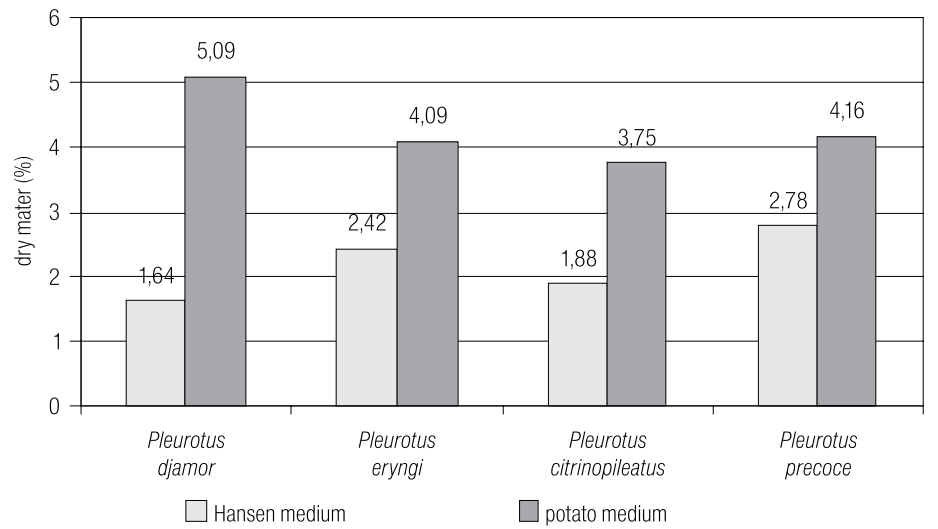

LSD $_{\mathrm{P}=0,95}$ for medium 0.54; LSD ${ }_{\mathrm{P}=0,95}$ for species 1.13; LSD ${ }_{\mathrm{P}=0,95}$ for medium and species 1.48

Fig. 2. Dry mycelium mass in the liquid stationary cultures depending on the medium and oyster genus.

The content of dry mycelium mass received on the liquid medium was depending on the medium composition and oyster genus (Fig. 2). Essentially higher dry mass showed the mycelium of all oyster genuses on the potato medium. The mycelium of Pleurotus djamor on the potato medium has 3 times more dry mass than mycelium on Hansen medium. Average irrespective of the oyster genus, there was $4,27 \%$ the dry mass on the potato medium and $2,18 \%$ on the Hansen medium. 


\section{DISCUSSION}

The compared mycelium growth of tested oyster genus was conducted under the temperature of $24^{\circ} \mathrm{C}$, which according to the $\mathrm{Ziombra}$ (1998) is appropriate for most trade genus's. All oyster genus's had more dry mass on the agar medium comparing the dry mass of the mycelium on the Hansen medium, which confirms the results received by Beeveri and Bilard (1970) and this confirms the stimulating effect of potato extracts on the mycelium growth. The results also confirm, that such temperature was also appropriate for the compared oyster genus. The mycelium growth depends on many factors, like compost, genus, variety etc, what also confirms the researches of Jamroz and Kalbarczyk (1994) and Ziombra (1998).

The mushroom growing in the liquid cultures (Grzybowski 1977; Milczuk 1985; Kopiński 1988; Stamets 1993) is usually conducted in the reactor to receive the mass of mycelium for food industry or defined biological active substance. Kopiński 1988 proved, that mushroom mycelium received in liquid culture is also suitable for mycelium production for mushroom growing. First conducted researches confirm that oyster mycelium can also be multiply in the liquid culture. This can help to receive quickly the better parental material as well as can help the further generalization of growing the less known genius the Pleurotus variety. In the available literature there are no information about growing the oyster mycelium in the liquid cultures for the reproduction of multiplication material.

\section{REFERENCES}

Beeveri R.E., Bilard E.G. 1970. The nature of the stimulation of fungal growth by potato extract. J. Gen.et Microb. 60: 273-279.

Gr zy b ow s ki R. 1977. Badania nad wgłębną hodowlą grzybów wyższych jako potencjalnego źródła białka. Przem. Spoż. 31: 372-374.

Ko pińs ki L. 1988. Otrzymywanie owocników grzybów wyższych z grzybni hodowanej metodą wgłębną. Grzyby 18 (6): 12-21.

J a m roz J., Kalbarczyk J. 1994. Ocena aktywności celulolitycznej płynów pohodowlanych Pleurotus ostreatus. Probl. Hig. 44:184-188

Milczu k Z. 1985. Wgłębna hodowla grzybów jadalnych. Grzyby 31: 30-36.

St a me ts P. 1993. Growing Dourmet \& Medicinal Mushrooms. Ten Speed Pres. Berkeley.

Zi o m br a M. 1998. Wpływ niektórych czynników na wzrost grzybni i plonowanie boczniaka. Rozprawy Naukowe AR Poznań, 278: 75.

Grzybnia boczniaka na pożywkach płynnych

Streszczenie

Materiałem wyjściowym do namnażania grzybni boczniaka w kulturach płynnych była grzybnia boczniaka na pożywce agarowej z banku odmian Katedry Warzywnictwa Akademii Rolniczej im. A. Cieszkowskiego w Poznaniu. Analizowano na pożywkach Hansena i ziemniaczanej wzrost grzybni następujących gatunków: boczniak żółty Pleurotus citrinopileatus, boczniak różowy Pleurotus djamor, boczniak królewski Pleurotus erynii i Pleurotus precoce. 